\title{
Engagement Cancellation and Its Legal Implication In Malaysia (Woman's Rights Perspective)
}

\author{
Uswatul Fikriyah \\ Sharia Faculty State Islamic University Maulana Malik Ibrahim Malang \\ uswatulfikriyah@yahoo.co.id
}

\begin{abstract}
Abstact:
This article aims to describe the legal implication of engagement cancellation in Malaysia and to analyze the woman's rights protection aspect in Act 303 Islamic Family Law Federal Territory 1984 in Malaysia. This article based on library research focuses on regulation Islamic Family Law Federal Territory Act 303 year 1984 of Malaysia, particularly concerning on about betrothal or Engagement. The result of this study show that the implication of engagement itself could open the opportunities to both of bride and groom to understand and know each other. The implications of engagement cancellation that can be taken from section 15 Act 303 Islamic Family Law Federal Territory. In Islamic family law in Malaysia especially Act 303 Federal Territory Islamic Family Law 1984 women have rights in accordance with their position, namely in the form of rights before marriage, the rights within marriage and the last is the rights after divorce. Women's rights protection aspects contained in the Act 303 Islamic Family Law Federal Territory generally not only in case of engagement cancellation or breach of promise of marriage (bethrothal) but in all the rights of women in marriage. It has the purpose to protect women's rights.
\end{abstract}

Keywords: engagement, family law, Malaysia

\section{Introduction}

Process of marriage in Malaysia is generally undertaken with various accompanying customs. The customs are acceptable in Islam as something good and reasonable. It provides many benefits such as peminangan or engagement ceremony procession. A promise to marry so called as peminangan in Malay culture is considered as a first process towards marriage. The agreement to marry or commonly called as a contract to conduct the marriage occurs when man raised the petition called by peminangan to the women. The petition is made directly by him or done indirectly through others who he trusts. ${ }^{1}$ Enactment or Islamic family law in Malaysia's States essentially does not give meaning specifically the term of engagement. But in one of its section mentions agreement for marriage that done orally or in writing and done directly or through intermediary i.e. the man who trust to express application to a girl. ${ }^{2}$

In Malaysia in the marriage act 303 Islamic Family Law Certificate Federal territories 1984 on part II about Engagement contained in section 15 mentions:

If any person has, either orally or in writting, and either personally or throught an intermediary, entered into a bethrotal in accordance with Hukum Syarak, and subsequently refuses without lawful reason to marry the other party, the other party being willing to marry, the party in default shall be liable to return the bethrotal

\footnotetext{
${ }^{1}$ Mimi Kamariah Majid, Undang-Undang Keluarga Di Malaysia (Kuala Lumpur: Butterworths Asia, 1992), 26.

${ }^{2}$ Majid, Undang-Undang Keluarga Di Malaysia, 15.

Jurisdictie: Jurnal Hukum dan Syariah Vol. 6 No. 2 Desember 2015
} 
gift, if any, or the value thereof and to pay whatever moneys have been expended in good faith by or for the other party in preparation for the marriage, and the same may be recovered by action in the Court. ${ }^{3}$

While, in Indonesia that the majority following the same view with Malaysia communityi.e. Syafi'i scholar is not set about engagement in Islamic family law Act. This is because the culture of Indonesia consider that Peminangan is not marriage contract and it can be cancelled by two parties. Only in the Compilation of Islamic Law (KHI) which is one of the regulations that set the marriage law in Indonesia. It is little set about peminangan that is set in article 1,11, 12, and 13. Entire article that set peminangan comes fromfiqh al-Syafi'iy. ${ }^{4}$ About legal implication of peminangan is described in article 13 containing two verses which basically explain that peminangan does not rise to a result or legal implication and the parties are free to cancel, because the sound is as follows: $:^{5}$ (1) Peminangan does not raise legal implication and the parties are free to cancel it; (2) Freedom to cancel peminangan is done with a good ordinance in accordance with local customs and religious guidance, so it stays made of harmony and mutual respect.

Engagement in Islam or the promise to marry is only an agreement to hold a marriage. So that one party is permitted to cancel an agreement when there is a clear reason or there is agreement between the two parties to cancel it. ${ }^{6}$ This engagement in the Malay culture is not a contract of marriage because basically there is not a marriage contract in it. So the engagement does not justify all restrictions for both men and women before the existence of a marriage contract. In the presence of an engagement are expected to presence of a wisdom that is to maintain a good relationship between Muslims so will not happen anything unwanted. Engagement can also prevent someone from hurting the other by marrying his brother's fiancé. This is because every Muslims are not allowed to marry his brother'sfiancéexcept it engagement canceled by the man. This is because the man has the right of a woman to not receive the marriage proposal from others.If an agreement is made, then both parties are bound by this agreement. Denying the agreement would lead to other parties will bear the losses and so on. After the occurrence of an engagement are not uncommon to break a promise made by the men. Not uncommon to break this promise was carried out not far from the day of the wedding.

This has resulted in some losses on behalf of women who have been preparing for the wedding party. This loss is not only in terms of property but also in terms of dignity (marwah) of woman. Engagement cancellation conducted by man in Malay culture can make the descent of dighnity (marwah), as well as give the impression of an insult to women. Many people, especially women, who are still a blur to their rights in cases of engagement cancelation that actually has been regulated by the term kemungkiran janji berkahwin. Many people often see engagement cancellation as paltry as they assumed that engagement is not something that is comparable to marriage. Part of them, assume that engagement is only custom before the occurrence of marriage. So, if there are parties who want to cancel it, there should not be a big problem between two families. There areEengagement cancellation case which was forwarded to the syariah Court and was decided by the Court. If we look at the decision of thesyariah court

\footnotetext{
${ }^{3}$ Legal Research Board, Islamic Family Law (Federal Territories) Act 1984 (Act 303) (Malaysia: International Law Book Service, 2012), 19.

${ }^{4}$ Amiur Nuruddin and Azhari Akmal Tarigan, Hukum Perdata Islam di Indonesia: Studi Kritis Perkembangan Hukum Islam dari Fikih, UU No. 1/1974, Sampai KHI (Jakarta: Kencana, 2004), 57.

${ }^{5}$ Pasal 13 ayat (1) dan (2) Kompilasi Hukum Islam

${ }^{6}$ Sayid Sabiq, Perkahwinan dan Pertunangan dalam Islam, (Subang Jaya: Al-Ramadhan, 1996), 59
}

Jurisdictie: Jurnal Hukum dan Syariah Vol. 6 No. 2 Desember 2015 
we can know that its decision contains the protection of woman's rights. In the case of Aishah vs Jamaluddin (1978), the men have broken a promise to marry the girl. Aishah demand repayment of Mahar amounted to RM25, RM800 for marriage expenses and claims she is entitled to continue to keep the engagement ring. ${ }^{7}$

Kadi Besar of Kedah as a judge for the case has decided to order the Jamaluddin to pay damages according to the engagement agreement and Aishah also reserves the right to continue to keep the engagement ring given to her.In addition, the judge also orders Jamaluddin pay the cost of bridal shirts to Aishah who has prepared for marriage and also RM400 as payment for the repair done specifically for the preparation of a wedding. In the engagement cancellation case between Salbiah Othman vs Haji Ahmad Abdul Ghani (2002), the woman had breached a promise to marry. The female has a claim for damages the stigmatization and reimbursed expenses include preparation for engagement and preparation for marriage. ${ }^{8}$ The Syariah High Court in Seremban was answer his application thatSalbiah against some claim covering bridal shirts, most fees are changing, most curtains and sheets, tents and deposits as well as bed covering legislative fees groceries and wet. Based on the background above writer is interested to describe the legal implication of engagement cancellation in Malaysia and analyze the woman's rights protection aspect in Act 303 Islamic Family Law Federal Territory 1984 in Malaysia.

\section{Research Methods}

This research is study in the field of law. This research focuses on regulation Islamic Family Law Federal Territory Act 303 year 1984 of Malaysia particularly concerning on about betrothal or Engagement. Therefore, this kind of research is normative legal research. This type of research also known as library research. This research used statue approach. Statue Approach done to search how engagement cancellation, and aspect woman's right protection after engagement cancellation according to Act 303 Islamic Family Law Federal Territory 1984 Malaysia and legal implication of engagement cancellation under article 15 which will help in analyze Process. ${ }^{9}$ The data sources used in the normative research is secondary data, which consists of primary legal materials; secondary legal materials, and tertiary legal materials. ${ }^{10}$ rimary legal material is the law is authority material does have the authority. As for primary legal materials in this research is the Act 303 Islamic Family Law Federal Territory 1984 Malaysia the secondary law materials in this research are books, thesis, journals and documents about aspect women's rights protection after engagement cancellation and legal implication of engagement according to Act 303 Islamic Family Law Federal Territory 1984 Malaysia. Among the secondary law Materials used in this research are: a. Ahmad Ibrahim : UndangUndangKeluarga Islam di Malaysia; b) Ahmad Ibrahim: Family Law in Malaysia and Singapore; c) compilation of Islamic law as the comparison settings regarding engagement in Indonesia and Malaysia; d) Asghar Ali Engimeer: The Rights of Women in Islam; e) Musawa

\footnotetext{
${ }^{7}$ Noraini Binti Md Hasyim, "Right of Muslim Women before and during Marriage, and Upon Divorce as Conferred by The Islamic Family Law (Federal Territories Act) 1984, Malaysia" (7th International Conference on Humanities and Social Sciences " ASEAN 2015 Challenger and Opportunies, Faculty of Liberal Art Prince Sonkla University, 2015), 586.

8 "Salbiah Othman Lwn Hj. Ahmad Abdul Ghani," accessed March 4, 2015, http://www.esyariah.gov.my/JurnalHukumSearch/htdocs/jurnalhukumsearch/JurnalHukumSearchDetailsPageB M.jsp.

${ }^{9}$ Tim Penyusun, Pedoman Penulisan Karya Ilmiah Fakultas Syariah (Malang: Fakultas Syariah UIN Maulana Malik Ibrahim Malang, 2012), 29.

${ }^{10}$ Peter Mahmud Marzuki, Penelitian Hukum (Jakarta: Kencana, 2010), 118.

Jurisdictie: Jurnal Hukum dan Syariah Vol. 6 No. 2 Desember 2015
} 
Journal; f) And other books that are still relevant to the study discussed. Tertiary law materials in this research are: 1) Legal Dictionary; 2) Malay Dictionary; 3) Encyclopedia of Islamic law. After the Legal material is collected than it analyzed to obtain the conclusion, in the form of legal materials analysis techniques is a Content Analysis.

\section{Result and Discussion}

\section{The Dynamics of Islamic Family Law in Malaysia}

The legal system applied in Malaysia is essentially based on the Common Law system of England (Anglo-Saxon). Islamic law and customary law is a source of law, especially in the field of personal status. Most aspects of the law are regulated by the federal law that is primarily based on the model of the United Kingdom at the beginning of the independence of Malaysia.A small portion of Muslimes life, especially in the area of personal status is regulated by each State which is called by the term of Sharia law. In this context, the states allowed to establish its own system of Islamic courts to enforce the application of Sharia. This Court commonly called as Sharia Court (Mahkamah Syariah). ${ }^{11}$ When Islam come to Malaysia in the 19th century XII-XIII, the view of Al-Syafie $i$ scholar became the version of Islamic law that is applied in Malaysia. As with the arrival of Islam in southeast asia and other parts through peace process, Islamic law in Malaysia adapt peace with local law commonly referred as customary law.In brief, there are several laws that ever existed and was still applicable in Malaysia, namely: the essence (intisari) and the proverbial tribe (pepatah suku) found in the custom perpateh is practiced by the tribes of Minangkapabu and Negeri Sembilan which are matriarchal.The law of Malay society is patriarchal mix with the Hindu law and in the customary Tamenggung. The maritime law essence in Malacca comes from Bugis and Makassar, and Islamic law from syafi ${ }^{\text {ee }}$ iy Scholar. ${ }^{12}$

The development of Islamic law on the colonial period also experienced various challenges. The arrival of the colonial arbiter cut theislamic development in Malaya archipelago. In addition, the arrival of England also has brought the English legal system was then applied in the Malaya. Because the colonizer then controlled politics and the military, then English law dominate the legal implementation in all areas of Malaysia. United Kingdom common law first brought and introduced to the Malaysian Malay society through the Civil Law Ordinance (legislation of civil law) in 1978. In addition to the civil law, criminal law , the implementation of civil and criminal law, and also contract law are imported by British from India which is basically also a principle of English common law was codified.After Malaysia became independent, all these laws remain in force. Civil law legislation having a revision in 1956 and 1972, and changed its name to the Civil Law Act 1956. In this civil law Act, it is clearly mentioned that the enactment is restricted by the existence of a rule of religion and local customs. ${ }^{13}$

When Malaysia have the independence, Malaysia birth as a Federation State in 1957 to provide a unique feature of Islamic law setting in Malaysia.Federalism is a concept of a federal institution that is composed of several states with a limited freedom with agreementto form a Federation. In the absence of the consent of the sultan and the willingness of other states to

\footnotetext{
${ }^{11}$ Nabiela Naily and Kemal Riza, "Hukum Keluarga Islam Asia Tenggara Kontemporer: Sejarah, Pembentukan, Dan Dinamikanya Di Malaysia,” Executive Summary (Surabaya: LP2M IAIN Sunan Ampel, 2013), 7.

12 Tun Zaki bin Tun Mohamed Azmi, "Singapore Academy of Law Annual Lecture 2011-The Common Law of Malaysian in the 21st Century," Singapore Academy of Law Journal 24, no. 1 (March 2012): 3.

${ }^{13}$ Azmi, "The Common Law of Malaysian," 5-6.
}

Jurisdictie: Jurnal Hukum dan Syariah Vol. 6 No. 2 Desember 2015 
join, unite and establish the Federation of Malaysia, then it will not appear. ${ }^{14}$ As a Federation States, the jurisdiction and authority is shared between the federal Government and the States. Although Islam is declared as official religion of federation government, Islamic religious affairs, handed over to the States. The basic law explains that the sultan is the head of Islamic Affairs in the each States. The Division of authority between federal and States refer to the federal Government list authority and State Governments that are listed in the Constitution. Essentially the federal Government regulates almost all of laws, both civil and criminal. However, Islamic law becomes Affairs of the State Government.Non-Muslim family law including the federal State Government authority under the civil court. While, the Muslim family law is a matter for the State Government under the jurisdiction of the Sharia courts. Criminal law, torts, contracts, agrarian and others include in to the authority of the federal Government that apply to Muslims and non-Muslims. ${ }^{15}$

Eleven of the thirteen British colonies at Malay became part of the Federation state then called Malaysia. Each states authorized in the form of legislation to identify an interpretation of Islamic law will be applied to the Muslims in their region and given the right to set up the judiciary to solve the case involving Muslims dispute that arises from the legislation. Among the matter of law that became the authority and regulated by the State is Islamic law and private law, marriage law, inheritance, wills, bequests (hibah), marriage, divorce, dowry, a living, adoption, trusteeship, gift, zakat, wakaf Division, Islamic Treasury, mosques and places of worship, criminal offences related to Sharia (except those regulated by the federal State). ${ }^{16}$ Including the authority of states is regulating the establishment and organization of the transition of the Sharia which will have jurisdiction over Muslims. The State also has control over the spread of the Islamic religion. In this jurisdiction, each State is free to impose their version related to Islamic law, and also free to establish Islamic court to solve dispute matter arising from Islamic law decided by the State. ${ }^{17}$ The Constitution of Malaysia allows the States to establish Shariah courts that prosecute Muslimes cases in his area. In the latest development, the federal Government gave authority to the State to decide matter related to Islamic law in each states region in the field of peminangan, marriage, divorce, adoption, a living, dowry, adoption, nasab and guardianship. All the matter is decided by using a law that decided by each state. While the legislation related to Islamic inheritance no one State which has made Act, so the matter of inheritance using fiqhto solve it. Because federal law regulates the rights of the material, then the Sharia Court and the civil court must cooperate in matters of inheritance in Islam. ${ }^{18}$

Since year 1952 (before the formation of Federation state of Malaysia in year 1957), until 1978, almost all States (including the Federal territory) sets the rules of the administration of Islamic law are the same. The legislation related to the appointment and authority of majelis agama of states, mufti, Shariah judiciary law, marriage and divorce and related violations of

\footnotetext{
${ }^{14}$ Azmi, "The Common Law of Malaysian," 5-6.

${ }^{15}$ Abdul Hamid Mohamad, "Harmonisation of Common Law and Shari'ah in Malaysia: A Practical Approach," 3-4, accessed October 4, 2015,

http://www.malaysianbar.org.my/speeches/harmonisation_of_common_law_and_shariah_in_malaysia_a_practic al_approach.html.

${ }^{16}$ Farid S Shuaib, “The Islamic Legal System in Malaysia," Pacific Rim Law \& Policy Journal 21, no. 1

(January 2012): 89.

${ }^{17}$ Najibah M. Zin, "The Training, Appointment, and Supervision of Islamic Judges in Malaysia," Pacific Rim Law \& Policy Journal 21, no. 1 (January 2012): 116.

${ }^{18}$ Zin, "The Training, Appointment, and Supervision of Islamic Judges in Malaysia," 95.

Jurisdictie: Jurnal Hukum dan Syariah Vol. 6 No. 2 Desember 2015
} 
Islamic law. The Federal territory became the first in a set of laws of Islamic family law prepared by the Office of the Attorney General's Office of the federal Government. When viewed from the contents, many of them which is a loan or an Islamic family law adoption of india and pakistan which are follow Hanafi and Maliki scholars .In these matters, the States have the option to follow draft of federal territory or follow draft of Kelantan which is strictly holds the view of Syafiei. Typically, in very controversial aspects such as restrictions on polygamy, some States are more inclined to follow Kelantan. While most of the rules in other States follow the pattern settings of Federal territory. ${ }^{19}$

In terms procedure code law, United Kingdom law influence is very strong. For example things related to relevance, accounting books, expert testimony, evidence of character, notice of session, the evidence of the contents of the document, the obligation of proof that everything comes from the British way of law.In some ways it still follows Islamic law, such as the problem of having two witnesses in the settlement of the matter in court, different treatment on witnesses who are immature and non-Muslims. However, there is no difference between the witness of men and women in the law of Sharia court in Malaysia. The hardest controversy in the process of codifying Islamic law in Malaysia in 1980 is related to Islamic Family Law. As mentioned earlier, there are two models which develop i.e Kelantan model which is conservatives and federal territory model prepared by common law experts. Most States follow the model of the Federal territory that was initiated by the federal Government. In the matter of the approval of wills married, in Kelantan and two other States (Kedah and Malacca) trustee still has the right to force his daughter to marry the Virgin as a common view of Syafie $i$ scholar. This Coercion is not possible done in model family law Federal territory model. ${ }^{20}$ Generally in Malaysia, family law is divided into two areas. First, which involves non Muslim society i.e. family law reform (marriage and divorce) Act 1976 and Muslim family law Act. Islamic family law Act (Federal Territories) 1984 (AUKI (WP) 1984) is a model for the legislation beside other several provision which established by each state. ${ }^{21}$ Various laws or Act or enactments that apply in every State generally have similarity. In this matter most of the legal experts and the literature said that an Islamic family law Act Federal territory 1984 and is the model and representation for Islamic family law features in Malaysia. ${ }^{22}$ The principle and the system of court in malaysia that is bifurcated between Islamic law and the Common Law of United Kingdom as described above had an impact in the ruling hierarchy. That Islamic law based and sourced in the text of syara' which is emphasizes on the evidence, the oath and the knowledge of the judge. While the Anglo Saxon system of United Kingdom is base on custom source and jurisprudence. Prepositions and the assumption that will give contribute that custom culture will naturally absorbed in legislation regulationand political law and practically developing into a judicial verdict. Both gave positive result i.e the legitimating of customary law and culture, although without formally enacted. ${ }^{23}$ However, the rules of engagement cancellation in Act 303 Islamic Family Law Federal Territory 1984 was strongly influenced by custom. Engagement in Malay custom can cause many implications both in terms of material and non material.

\footnotetext{
${ }^{19}$ Naily and Riza, "Hukum Keluarga Islam Asia Tenggara," 11.

${ }^{20}$ Naily and Riza, "Hukum Keluarga Islam Asia Tenggara," 11.

${ }^{21}$ Naily and Riza, "Hukum Keluarga Islam Asia Tenggara," 12.

${ }^{22}$ Naily and Riza, "Hukum Keluarga Islam Asia Tenggara," 13.

${ }^{23}$ M. Samir Fuadi, "Peran Urf Dalam Formalisasi Hukum Peminangan Di Malaysia Dan Pakistan Menurut Tinjauan Dalil Al-Qur'an Dan Sunnah,” Al-Mu'ashirah 10, no. 1 (January 2013): 83.
}

Jurisdictie: Jurnal Hukum dan Syariah Vol. 6 No. 2 Desember 2015 


\section{Legal Implication Of Engagement Cancellation in Malaysia}

In Malaysia, the law applicable to Muslim on family matters is the Islamic Family Law Act or Enactment which is varying according to each state. As Muslim matrimonial matters are within the state affairs in Malaysia, each state is governed by its respective family law enactment. The statute applicable to Federal Territory of Putrajaya, Labuan and Kuala Lumpur is the Islamic Family Law (Federal Territories) Act 1984 (Act 303) which considered as the main Act. ${ }^{24}$ Basically, Malaysian engagemnet is not an obligatory thing that shoud be done before marriage. However, malaysian custom considered that engagement is one of the significant phase to be done before marriage taking place. ${ }^{25}$ Just like what has already mentioned in previous explanation. According to Datin Noor Azizah Mohd, ${ }^{26}$ engagement is a Malaysian custom which has received by muslim and it is not a sacret thing that should be done. By following this kind of engagement, both two bride and groom are given space periode to recognize and understand each otheres personality. Malaysian engagement is so important to be done before coming to the marriage phase. It is about the agreement between two families that will held a marriage, and it is purposed as the advance whether they will continue their marriage or not. The marriage desire might proof clearly from explicit words. The ceremony of bethrotal is merely a declaration to the public that the marriage between the parties will take place in due course of time. However it may be noted here that betrothal does not give any right and duty between the parties. ${ }^{27}$

Marriage in Malaysia is often though not always preceded by a betrothal or engagement. ${ }^{28}$ Engagement is an agreement between a man and a woman to have a marriage. A ring or another gift that given at the engagement event used as the sign of the engagement. 96 From the Muslim Family Law Legislation in Malaysia, it is considered as a contract that bond both two sides. Muslim View defined, every single contract that has signed should be obedient as long as the contract is not incompatible with the islamic law. The implication of the contract is only depend on human's right. In term of amanah aspect in fulfilling a promise included to the engagement case, just like what God has emphasized in surah Al-Maidah verse: 1: depend on the signification of Muslim law. However, the only thing that become the main pressure is the only one who will carry on the detriment after the engagement cancellation happened where the burden evidence to the detriment has guaranteed placed to the side that is prosecute in the court (Mahkamah). Concerning the engagement cancellation in Malaysia that follow on Act 303 Islamic Family Law Federal Territory 1984 Malaysia of the section 15. The Syariah Court might help to the one of the two side who has suffered. According to the previous section, it can be seen that an engagement is a kind of thing which has an implication, it is about law that is able to bond both two parties until it has the same meaning with a contract. The implication

\footnotetext{
${ }^{24}$ Anis Shuhaiza Bt Md Salleh and Noor 'Aza Bt Ahmad, "Cross Boundary Marriage Under Malaysian Family Law: Between a Dream of Life and Reality of Legal Requirements," Journal of Politics and Law 3, no. 2 (September 2010): 2, doi:10.5539/jpl.v3n2p148.

${ }^{25}$ Ahmad Ibrahim, Undang-Undang Keluarga Islam Di Malaysia (Kuala Lumpur: Malaysian law Journal, 2000).

${ }^{26}$ Prof. Datin Noor Aziah is senior lecturer of Family Law, Woman, and Children Universiti Kebangsaan Malaysia (UKM), she is also as Timbalan Naib Conselor (Hal Ehwal Pelajar dan Alumni) UKM.

${ }^{27}$ Mohammed Ahmad Qureshi, Muslim Law of Marriage, Divorce and Maintenance (New Delhi: Deep \& Deep Publications, 1995), 60.

${ }^{28}$ In the parts of Negri Sembilan and Malacca which follow the Adat perpateh or old Malay custom a marriage is regarded not just as personal but a family and tribal tie as wel and there are usually fprmal engagement ceremonies including an engagement feast to which the tribal chiefs are invited, their presence being regarded as tacit approval of the union - see Haji Mohamed Din bin Ali, "Two Forces in Malay Society”, (1963) I. INTISARI 25 (3)

Jurisdictie: Jurnal Hukum dan Syariah Vol. 6 No. 2 Desember 2015
} 
of engagement itself could open the opportunities to the both of bride and groom to understand and know each other. By having the engagement, both the bride and groom might see how they are exactly in certain limitation. The man can see hoe the woman and the opposite of it. Section 15 of Act 303 Islamic Family Law Federal Territory 1984 Malaysia stated: "When the Person bond an engagement depend on the islamic law, whether it is according to the spoken or written and whether it is according to himself of the mediator.

However when one of the two parties decided to cancel the engagement with no logical reason, and the other one has no the same decission, they might need: a. Return back all the gift he/ she received. But if he or she could not retun back, it might be changed by money with the same amount of the gifts. $b$. The one who cancel the engagement shoukd carry the financing that has used by changing it with the equipment need to the marriage. Both of two things mentioned must be changed by the one who decide to cancel the engagement. But if they do not want to change the finance, the other one who receive the marriage might prosecute or demand the remidi to the Syariah Court through section 15 or the Act that has mentioned above." However, when the one who cancel the engagement has the concrete reason and it is true according to Syarak, then the one who cancel the engagement do not need to change two requisites to be replaced just what section 15 explained. It needs to be explained that section 15 does not give the explanation specifically about the requisites that should be replaced for the one who become the victim of the engagement cancellation. In fact, the engagement cancellation oftenly happent in Malaysian society. In many cases, the replacement in cahanging the detriment can be throught the deliberation in a good way by both families. Eventhought, often times one of them are basically does not satis fied with what has already decided or the cancellation and the requisetes replacement. Marriage bond is an agremeent where both the man and the woman are agree to have a marriage in the following day and in the day where both of the families are agree.

In Malaysian society, the engagement process is held depend on the customs law, in this case, the bride and the groom should follow the Merisik phase before the engagement association is hold. Implication of engagement cancellation formulation that can be taken from section 15 Islamic Family Law Federal Territory 1984 Malaysia are: 1. The only one side who cancel the engagement have to return all the gift and give the requisites replacement change. 2 . For the one who has the unwilling engagement without any reasonable reason will be given a punishment to replace the requisite. 3 . The one side who cancel the engagement should pay the things that has already spent to prepare the engagement and wedding party. It has explained clearly that an engagement protect by the law Act. So that for those arranged the marriage should not be arbitarily in deciding or cancelling the engagement. However, the man side or the woman side even the parent of both the man and the woman could cancel the engagement in clear reason and under the requirements that the cancellation has agreed by both of families. So that, if the cancellation happen because the disability of the bride or the groom candidate or they find imperfection even the engagement, and it is depend on their agreement. The legal engagement can be proofed by having an authentic evidence and as long as they have an agreement sign on materai. In another hand, when one of the bride and the groom cancel the engagement without clear reason and could not be corrected. The one side who cancel the engagement must change the financial loss everything that related to engagement and marriage cost. This section clearly differenciate between an engagement cancellation a reason and without reason.

The legal engagement cancellation is when it has agreed by both two sides. This explanation also explained in the next verse that state that whether the other side is still expect

Jurisdictie: Jurnal Hukum dan Syariah Vol. 6 No. 2 Desember 2015 
the engagement. When this kind of thing happen, the one who cancel the engagement might be demanded in syariah court, and if he or she proofed that they find the mistake, he or she must replace the requisite determined. The one who cancel the engagement must pay all money that has expensed to prepare the wedding party. For example, when the man cancel the engagement, he must replace all the gifts to the woman like ring, clothes, food and all things must be replaced. For the food who has run out, need to be counted the amount of the food. And the woman also has the right to has the gifts absolutelly in case both two parties are agree to end the engagement. It is also obtain for the woman mistake. ${ }^{29}$ It is also obtain for the things that has lost or run out, it must be cahanged. It also prevail when the woman who cancel the engagement. According to explanation of this section, the one sides who became the victim of engagement cancellation, whether the man or the woman do not need to return back all things he or she received. The amount of the detriment that he or she got must be counted up that it can be reported and then demanded in the Syariah Court. The one side who cancel the engagement might be demanded to pay all the expenses that had been prepared by the other side.

On the contrary, the one side who had been the victim could make an accusation to the syariah court if the other side who cancel the engagement does not want to pay the detriment requisite by having the conference and deliberation between two families. However, in this case the one side who demand the detriment of engagement cancellation need to prepare the evidence and the witness to strengthen the accusation in the syariah court. Several thing that sould be noticed from the section 15 of the IslamicFamily Lw Federal Territory are: ${ }^{30}$ 1) Engegement is the first main contract before the marriage take place. For all sides who had promised to marry must obey the engagement agreement except they find a huge possibility that will lead to the depraved and they will get dangerous when the continue thei marriage; 2) When one of the parties cancel the engagement, he or she must pay the detriment for all the equipment that has prepared by the other side to hold the wedding parrty. Beside, he or she must return back all the gifts that had given for the engagement; 3) When one side felt lost out of the engagement cancellation, she or he coukd prosecute in the Syariah Court; 4) As the evidence form of the detriment, it needs autenthic proofs like financing receipt and the purgative of the payment to prepare themarriage; 5) When the man cancel the engagement, the woman might prosecute the man in Syariah Court. And the opposite of it. The man also might prosecute the woman as long as he has strong evidence that can be proofed; 6) Reasonable or not an engagement cancelled will be evidenced by the Court's action which will be reinforced by witnesses and evidences Jurisdiction of Syariah Court as described above, if the Party who cancel the engagement with the legal reason and true according to Islamic laws, he or she does not have to meet the both claim described in section 15. And if both of them agree to make peace and forgive each other. But if one of the parties disagree and demand justice, then one of parties may submit deman on the syariah Court based on this section 15 .

The judge will decide the amount to be paid by the party who cancel the engagement fairly. And all parties in this case would be willing to acceptthe Court decission despite not satisfying. This is the jurisdiction of the syariah courts in protecting Muslims in accordance with the enactment of the administration of Islamic family law. Therefore, Sharia Court has no power or right to hear the demand except from the things that have been described above. So, compensation damages because of the humiliated by the party who cancels the engagement

\footnotetext{
${ }^{29}$ Majid, Undang-Undang Keluarga Di Malaysia, 25.

${ }^{30}$ Noriah Idris, "Dilema Putus Tunang," accessed February 6, 2015, http://musaawang.blogspot.co.id/2011/11/dilema-putus-tunang.html. Jurisdictie: Jurnal Hukum dan Syariah Vol. 6 No. 2 Desember 2015
} 
cannot be filed in the Syariah Court. This is because the compensation of ashamednes is not the jurisdiction of religous matter. According to the explanation of seksyen 15, which mean as engagement gift is the gift that is given in the engagement party (majlis pertunangan) or gift that can understand as gift of marriage preparation. Therefore, for the gift that given before the engagement is not an engagement gift but is a gift or giving before engagement and thus it cannot be demanded in the Syariah Court. Gift given before the engagement was defined as gifts or grants. ${ }^{31}$ Marriage is not unimportant matter that can be taken lightly. It involves the destiny of someone. More over,each side of things in a person's life in surviving in daily life. Because it is a very important matter, therefore, Islam provides a medium that the aim is to give time to both sides to get acquainted and see to what extent the existence of potential compatibility to the parties involved to build a household and family life. Prophet Muhammad SAW suggests that the engagement better to kept. The aim is to save the dignity of both parties can be taken care of and preserved in the event found an unsuitable or not compatibility between those involved. Alternatively, the marriage could not be carried out for reasons permitted under Islamic law. According to Aliaz Azhar ${ }^{32}$ an engagement has led to an implication where engagement is included in the contract form which requires the parties to implement the contract.

As a religion that stresses morals and etiquette, then it should be a period of engagement is undertaken in the munasabah or clear period, because it can give a clear time to both sides to make judgments and decisions. Despite the cancellation of engagement need to be done by one of the parties, but it must be done in a good behavior and civilized as well as done since the beginning before the other partymaking preparations for a wedding. In the event of cancellation or default on an engagement to marry made without justifiable (reasonable), and the other party has made preparations to hold a wedding party, then based on the explanation of law mentioned earlier, those who breached the promise can claim damages through the Syariah Court. Damages will be assessed by the Court are based on the all expenses and necessary arrangements have been made by the parties related to majelis or wedding party. If the partiescancel the engagement has a valid reason and allowed by Islamic law, he or she does not need to meet both the requirements set out in section 15. The Islamic family law (Federal Territories) Act 1984 (Act 303) have no specific explanation about the use of Islamic law as in nine other States in Malaysia. Provisions on the use of Islamic law gives the meaning that all explanations or interpretations of the explanation is not appropiate with Islamic law is not valid according to the inappropiate, and if any act or if there is a matter not described expressly in the Act or law, the obligation of the Court to use the Islamic law regulation. This explanation can give a sense that the compensation claim against the cancellation of engagement may be prosecuted in Shariah Court on condition that the party that claims it can prove the truth about losses and not contrary to the law of syarak. The claimant in the Syariah Court that let convince Syariah Court that his or her claim is not off of what the Islamic law before a court can give the order to she or he who cancel the engagement to pay damages as a result of the feeling of shame once the engagement cancelled without legal cause. However, the burden of proof placed on the claimant to prove that it is not contrary to Islamic law.

However, not all cases of breach of promises to marry give the right to Muslim woman to make claims for damages. Just cases of breach of promise to marry that actually involve

31 "Pemungkiran Pertunangan," accessed March 4, 2017, https://senadakpwkm.wordpress.com/2011/02/16/pemungkiran-pertunangan/.

32 Aliaz Azhar, Interview (Malaysia, 01 October, 2014)

Jurisdictie: Jurnal Hukum dan Syariah Vol. 6 No. 2 Desember 2015 
losses are allowed to demand for damages in the same form, in the form of money or another form. In Malaysia claim or application related to damages of engagement cancelation to the syariah Court in each States. ${ }^{33}$ The Court which has the right to solve this claim is Syariah Court as enshrined under the administration of Islamic law (Federal Territories) 1993 explaining the Syariah Court has jurisdiction to hear matters of the engagement, marriage and so on. ${ }^{34}$ Therefore, the civil courts have no jurisdiction to solve a claim in relation to engagement cancellation. Explanation of article 121 (1A) of the Constitution also issued the civil courts from having jurisdiction solve things where the Syariah Court has jurisdiction on the matter. Despite claims for engagement cancellation have been deleted in England. In the case between Doris Rodnigues vs Bala Krishnan. The Hight Court decided that civil law Act 1956 and Contracts Act 1950 is still going on and in use. However for Muslims, it's obvious that the civil courts no longer had jurisdiction in the matter of engagement cancellation since this matter included in the jurisdiction of the Syariah courts. ${ }^{35}$

Engagement is only an agreement to hold marriage and indirectly creating the marriage by itself. Therefore, in principle both of man and woman may cancel the agreement, if there is a valid reason that allowed him to do it. However, such an agreement should not be cancelled without reasonable cause. ${ }^{36}$ Engagement in Malaysia commonly held following custom that used in community. Engagement is defined as the beginning of the marriage and it is recommended that both parties are acquainted with each other before the wedding and then the marriage was held after both parties had seen and consider each one. Custom of engagements are basically brings many benefits and can strengthen both families before the marriage takes place. The Customs also urged the parties to give gifts between them and therefore bring honor and affection between them. In Malaysia there is a custom of the community which is mostly done between the parties who engaged. In this agreement is if the man cancel the engagement and did not want to marry, she shall not be demanded back the gifts given by him. Conversely, if the woman cancels the engagement, she should pay double the money and goods that have been given by the man. This custom is very detrimental to the women where the men can get twice as much for what he gave to the woman if the cancellation of the engagement done by the woman. Although the engagement is onlya promise to hold a wedding, an engagement cancellation without any cause is indecencies are hated by God, as God's word in the surah alSaaf verse 3: Illegally an engagement of someone except it meets two conditions, namely the absence of impediments of syar'i that hinder the legitimate of marriage and permitted by syarak to do marriage. Islam prohibits absolutely the engagement above other people's engagement and engagement during the waiting time (iddah). In addition to the Islamic Family Law Act Enactment Federal Territory in 1984, the issue of engagement cancellation is also contained in the civil law as the Breach of Promise of Marriage action. Muslims in Malaysia can demand for damages relating to the engagement cancellation in Civil Court because the Common Law which is followed by Malaysia said that the engagement was entered as a contract.

Based on civil Family Law in Malaysia which is based on the Law Reform (Marriage and Divorce) Act 1976 or commonly known with the LRA explained about the cancellation of the engagement with the term Breach of Bethrothal. In this case the LRA States that in the event of

\footnotetext{
${ }^{33}$ Zulkifli Hasan, "Hak-Hak Wanita Islam Dalam Kes Mungkir Janji Untuk Berkahwin Di Malaysia : Kajian Perbandingan Antara Undang-Undang Sivil Dan Syariah,” Jurnal Hukum 20, no. 1 (2005): 15.

${ }^{34}$ Seksyen 46 ayat 2 huruf a Act 505 Akta Pentadbiran Undang- Undang Islam, Wilayah Persekutuan 1993,

${ }^{35}$ Ibrahim, Undang-Undang Keluarga Islam Di Malaysia, 25.

${ }^{36}$ Ibrahim, Undang-Undang Keluarga Islam Di Malaysia, 20.

Jurisdictie: Jurnal Hukum dan Syariah Vol. 6 No. 2 Desember 2015
} 
annulment of betrothal may give rise to some of the consequences as follows: ${ }^{37} 1$. Damages There are two kinds of damages, namely general damages, namely general damages and special damages a. General damages Damages for the abstract, i.e. breach of promise to marry. In assessing the proper amount of damages, the judges are not limited to the mere pecuniary loss which the plaintiff has sustained, but may take into consideration the injured feelings and wounded pride of the plaintiff. The damages in an action for breach of promise of marriage are not measured by any fixed standard and are almost entirely in the discretion of the court. They may be of a vindictive and uncertain kind, not merely to repay the plaintiff for temporal loss but to punish the defendant in an exemplary manner. No measure of damages can be laid down, save that, while in aggravating circumstances the damages may be at large, they should not be fixed as though they were a fine. In assessing damages, the injury to the affections of the plaintiff, the prejudice to his or her future life and prospects of marriage, the rank and condition of the parties and the defendantes means are all matters to be taken into consideration. The conduct of the parties may properly be considered in aggravation or mitigation of the damages. b. Special damages Damages for specific items and which may be quantified in monetary terms, such as damages for medical expenses and wedding preparation. 2. Return of gifts (rings) in the absence of agreement to the contrary. ${ }^{38}$ Only the wrongful party (defendant) should return the gifts and ring to the plaintiff. If the contract to marry is dissolved by mutual consent, both parties must return the engagement ring and gifts. If the marriage does not take place either through the death of the person giving the ring or other conditional gifts, it should be implied that the gifts shall be returned. Beside general and special damages, there is a need to consider the gifts and rings which are usually exchanged or given to celebrate the engagement. The common law may be resorted to in the absence of any express agreement thereto.

\section{Woman Protection Aspect in Act 303 Islamic Family Law Federal Territory 1984 Malaysia (Woman's Rights Perspective)}

Writer can see that in this regulation contain of woman's rights protection in Islamic Family Law in Malaysia especially is Act 303 Islamic Family Law Federal Territory 1984 Malaysia. It is one of big excess of Islamic Family Law Malaysia than Indonesia. If further reviewed in Islamic Family Law in Malaysia would seem that the legislation of Islamic family law in Malaysia has a protectionist nature towards women's rights and meet practical gender needs. Islamic family law in Malaysia at least so pay attention to the rights and obligations between men and women (both the prospective bride and groom, husband and wife as and also the ex-husband and ex-wife). In Islamic family law in Malaysia especially Act 303 Federal Territory Islamic Family Law 1984 women have rights in accordance with their position, namely in the form of rights before marriage, the rights within marriage and the last is the rights after divore. ${ }^{39}$ First, regarding women's rights at the time before marriage there are two rights that become interest i.e rights at the time of the engagement and the right application of the guardian (wali hakim). Secondly, the rights of women in marriage, namely in the form of rights to acquire a living themselves, the right maintain children, and the right to earn a living for the children. Third, the rights of women after marriage breakdown that includes the right to earn a living (nafkah), mut'ah, acquire divorce property, parenting, and the right to earn a living

\footnotetext{
${ }^{37}$ Nuraisyah Chua Abdullah, Family Law for Non-Muslims in Malaysia (Selangor: International Law Book Services, 2006), 7.

${ }^{38}$ Nuraisyah Chua Abdullah, Family Law for Non-Muslims in Malaysia, 8.

39 “Hak-Hak Di Dalam Undang-Undang Keluarga Islam,” accessed January 29, 2015, http://senadakpwkm.wordpress.com/2011/02/14/hak-hak-di-dalam-undang-undang-keluargaislam/.
}

Jurisdictie: Jurnal Hukum dan Syariah Vol. 6 No. 2 Desember 2015 
(nafkah) for children. ${ }^{40}$ The fact shows that there are some interesting cases in the Islamic family law in Malaysia that has been trying to integrate the elements of protection of women's rights. Intergration against women's rights is done in various ways. Among the ways used is by provide regulation in the articles contained in the Act 303 Federal Territory Islamic Family Law against the deeds that potentially damage to women's rights. One of the ways that it is interesting to note is on the implications of engagement cancellation in the Act is known by pembatalan janji berkahwin where the regulation in this Act is very different when compared to Indonesia in the Marriage Act, namely Act No. 1 of 1974 which in it is not regulate about engagement. ${ }^{41}$ Only in the compilation of Islamic law which is one of the references to regulations of the family law in Indonesia which is basically not ratified as law only in the form of presidential instruction. In the bit of Compilation of Islamic Law mentioned about peminangan in some of its articles i.e. article 1,11, 12 and 13, but in the articles explained that peminangan can be freely for cancelled without any implications. As in article 13 of Compilation of Islamic Law states: 1) Peminangan does not raise legal implication and the parties are free to cancel it; 2) Freedom to cancel peminangan is done with a good ordinance in accordance with local customs and religious guidance, so it stays made of harmony and mutual respect.

While the Act 303 Islamic Family Law Federal territory in 1984 with the firm mentioned in section 15 as follows:

If any person has, either orally or in writing, and either personally or through an intermediary, entered into a bethrotal in accordance with Hukum Syarak, and subsequently refuses without lawful reason to marry the other party, the other party being willing to marry, the party in default shall be liable to return the bethrotal gift, if any, or the value thereof and to pay whatever moneys have been expended in good faith by or for the other party in preparation for the marriage, and the same may be recovered by action in the Court. ${ }^{42}$

As known that cases of engagement cancellation much happening in Malaysia. But, from the aspect of losses suffered may not like a negative impact and losses amounting that suffered by women. ${ }^{43}$ The form of consequence that can the heavy burden for women not only in terms of the material where the women are prepare for engagement party and prepare for the wedding. However, the impact in the form of negative feelings of shame in terms of dignity, feeling cheated, humiliation and etc. The history of formation and modernization of Islamic law especialy family law in Malaysia in Act 303 Islamic Family Law Federal territory cannot be released from the debate surrounding gender. Until now, the writer can draw an understanding that gender issue in Malaysia is closely associated with the realm of law and legislation, especially in the Islamic marriage law. The realm of marriage is closely related with gender issues because of marriage changing the legal status of women dramatically. ${ }^{44}$ So it is much related to women's rights in their role in the realm of marriage. The role of the position of Islamic family law is very important and strategic in setting rules which will establish and support the attainment of the wedding order based on justice and equality of gender, where women's rights are an important concern. Act 303 Islamic Family law the Federal territory,

\footnotetext{
40 "Hak-Hak Di Dalam Undang-Undang Keluarga Islam."

${ }^{41}$ Naily and Riza, "Hukum Keluarga Islam Asia Tenggara," 19.

${ }^{42}$ Legal Research Board, Islamic Family Law (Federal Territories) Act 1984 (Act 303), 19.

${ }^{43}$ Naily and Riza, "Hukum Keluarga Islam Asia Tenggara," 20.

${ }^{44}$ Naily and Riza, "Hukum Keluarga Islam Asia Tenggara," 5.

Jurisdictie: Jurnal Hukum dan Syariah Vol. 6 No. 2 Desember 2015
} 
according to the writer can be a device to support the realization of Justice and gender equality especially in protecting women's rights in marriage.

Women's rights protection aspects that contained in the Act 303 Islamic Family Law Federal Territory generally not only in case of engagement cancellation or breach of promise of marriage (bethrothal) but in all the rights of women in marriage in accordance with the mandate of CEDAW (Convention on the Elimination of All Forms Discrimination Against Women) to ensure that laws and policies that apply in countries in different parts of the world are responsive to gender issues. ${ }^{45}$ The purpose of the Islamic Family law that pays attention to aspects of the protection of women's rights is to provide justice to women so that women get the appropriate rights and spared from the oppressive measures. Beside that, it also aims to allow the women to demand the rights that should be granted based on the laws of syarak. Section 15 of Act 303 Islamic Family Law Federal Territory 1984 Malaysia explained that women have the right to claim all the granting at the time of engagement if the engagement cancellation is done by the men and women may claim any damages as a result of the engagement cancellation through action in the courts. Women's rights protection aspects in this section lead to that of women who intend to get their rights as demanding the compensation for preparation of wedding party can be done by making a petition in the Syariah Court of each states. Aliaz Azhar ${ }^{46}$ said that Regulations Section 15 Islamic Family Law Federal Territory 1984 themselves contain a purpose, namely as a protection to the rights of women. As the implications of engagement in Malaysia where it is when a woman has approved an engagement her rights will be closed to receive pinangan from the other men. In the case of a claim for engagement cancellation, the syariah Court clearly had jurisdiction in the case of a claim the engagement cancellation. It contained clear in the Islamic Administrative Enactment States Malaysia. Although the cases under review involves Muslims who are judged in civil court for example the case between Nafisahvs Abdul Majid and Hamzah Musa vs Fatimah Zaharah Mohamad Jalal.

This cases was decided by the Civil Court before moving the Constitution i.e in year 1988 where article 121 (1A) of the Constitution explicitly provides for exclusive jurisdiction the Syariah Court in the cases of Islamic family contained in Islamic Administrative law States Malaysia (Undang-Undang Pentadbiran Islam Negeri-Negeri Malaysia). ${ }^{47}$ Asghar never condemn for state interference on marriage as long as it will create welfare and social justice. Furthermore, he praises several states for their family law which accommodate human right and treat the marginal group equally. For instance, he praises several countries which restrict or forbid polygamy such as Pakistan, Libya, Lebanon, Iraq, and Jordania. He never condemns the interference of the state as long as it provides the true Islamic justice. In other hand, he criticizes an implementation of injustice regulation, especially toward marginal group (oftently woman) such as Saudi Arabia. ${ }^{48}$ The interference of government through this regulation is another effort to bring social justice for society. It is similar to the role of Muhammad as explained by Asghar as the leader of government in creating social justice.

Muhammad revealed Islamic value and law to improve social injustice occurred in his society. In this matter, Muslim ${ }^{\text {ee }}$ s marriage as regulated by Malaysia"es Governments in Act 303

\footnotetext{
${ }^{45}$ Naily and Riza, "Hukum Keluarga Islam Asia Tenggara," 6.

${ }^{46}$ Aliaz Azhar, interview (Malaysia, 01 October, 2014)

${ }^{47}$ Hasan, "Hak-Hak Wanita Islam," 14.

${ }^{48}$ Asghar Ali Engineer, "Islam, Women, and Gender Justice," in What Men Owe to Women: Men's Voices from World Religions, ed. John C Raines and Daniel C Maguire (New York: State University of New York Press, 2001), 164.
}

Jurisdictie: Jurnal Hukum dan Syariah Vol. 6 No. 2 Desember 2015 
Islamic Family Law Federal Territory Malaysia 1984 is an effort to create equality rights between man and woman in marriage life. Aranging of its Act is as effort to repair the woman $\mathrm{s}$ position in marriage. This happen because Malay Custom, woman has the lower position than man. Here, woman es rights try to be protected in the time before marriage, inside marriage and after divorce. Women and children are the strengths of future generation because they are the backbone of families. In almost all cases, women are the one who are disadvantaged by the inequalities enshrined in the various legal orders accommodated by the state. While more structured institutions had been developed to make women more competitive in economic and education sectors, not much success has been achieved in protecting women and children in family disputes, conversion of religion and custody issues in Malaysia. Family is a foundation of a society. Women are always the backbone of families even in fundamental patriarchal society like Malaysia. Hence the arranging of the articles contained in the family law legislation in order to adapt the legal Islamic thoughts with the times and the context when the rule was created. In this matter the custom of Malayisian Society especially engagement According to Asghar Ali Engineer Qur'an considers women and men are equal in their mental, abilities, and moral. Both sexes were equally given a reward or punishment for good and evil deeds thattheir have done. Therefore, Asghar looked that the Qur'an is treating both sexes the same human in terms of moral responsibility as well as reward and punishment. ${ }^{49}$

This logically extends into the sphere of marriage. In Islam, marriage is a contract between two equal partners. A woman as the equal of the man may assign the terms she wanted and also a man . Therefore, Man are not higher in his position. In this case Asgahar provide equal rights for man and woman in marital. For Asghar, woman is entitled to determine the terms of the marriage in accordance with the desire of women for not breaking syarak. Asghar also did not agree with the concept of wali mujbir which give full fredom for guardian to choose a man and marry a woman who under his guardianship without approval of woman. The woman's agreement is must be in carrying out the wedding. Hak ijbar basically to help girls so they do not wrong in determine option. This is in accordance with the opinions of Yusuf Qardhawi are leaning more to the opinion of Imam Abu Hanifah, who handed over the Affairs of the woman with the requirements from her. ${ }^{50}$ The equality between man and woman according to Asghar have the logical consequence that engagement cancellation which is done by the man or woman, they have same obligation and rights for the implication of engagement cancellation. Therefore Malay custom in Malaysia which obliged to woman who cancel the engagement has the obligation to return twice as much had been given gifts from a man is very contrary to the principle of equality of man and woman in the perspective of Asghar Ali.

In Islam, there are principles of marriage i.e.which are: 1) the choice of the right partner, 2) marriage preceded by peminangan, 3) there are provisions on the prohibition of marriage between men and women, 4) marriage based on voluntary Marriage between the parties concerned, 5) there is testimony in the marriage contract, 6)marriage is not defined for a specific time, 7)there is an obligation to pay a dowry upon husbands, 8) there is freedom of filing requirements in the marriage contract, 9) rresponsibility to become head of the family is the husband, 10) There is an obligation to get along well in domestic life. ${ }^{51}$ In the Qur'an surat An-

\footnotetext{
${ }^{49}$ Asghar Ali Engineer, Hak-Hak Perempuan Dalam Islam, trans. Farid Wajidi and Cici Farkha Assegaf (Yogyakarta: Lembaga Studi dan Pengembangan Perempuan dan Anak, 2000), 137.

${ }^{50}$ Yusul al-Qardhawi, Al-Ijtihad Al-Mu'asir Bain Al-Indibat Wa Al-Infirat (Kairo: Dar al-Tauzi, 1992), 26.

${ }^{51}$ T. O. Ihromi, Sulistyowati Irianto, and Achie S. Luhulima, Penghapusan Diskriminasi Terhadap Wanita (Bandung: Alumni, 2000), 148.
}

Jurisdictie: Jurnal Hukum dan Syariah Vol. 6 No. 2 Desember 2015 
Nisa ' paragraph 34 stated that the man was a leader for women, does not mean the man can do arbitrary detention against women. In the Islamic family law also contained several provisions that give protection to a woman, in the sense of providing certain rights for women proportionately. Regardless of the rights of woman in marriage in rights before marriage is rights in Khithbah (the proposal) that is when man have the right to see a woman that has been proposed, these rights also apply to woman, means that women also allowed to see man before marriage, because woman are also entitled to determine her choice. Similarly, in matter of engagement cancellation, the woman has the right to cancel an engagement, for example when it is known the existence of physical or mental disability in one of the parties takes place some time after the engagement that will prevent the purpose of marriage. ${ }^{52}$ Islam gives women the new status. This religion wants to create a new woman as it also wants to create a new man. Women are given full autonomy in terms of marriage. Marriage depend on the agreementof a woman which given according to requirements she asked for.

Asghar argue that marriage in islam are contractual. In other words, either the man as well as woman can set the reqtirements of the marriage. This requires that women are free to decide if she wants to do the marriage contract or not. In this case the woman in the period between peminangan and weddings has the right to cancel the engagement if there is a reason that is justifiable by syarak. Such as the existence of a disability, a bad attitude or anything else that can be harmful for household life.According to Asghar in the guardian is able to choose her future husband. However, according to himwoman have the right to accept or reject applications from man. Her father or anyone can ${ }^{e c} t$ force her to accept a marriage proposal from a man. ${ }^{53}$ Qadi, or anyone who organizes weddings, can't do their job without approval of the woman and the requirements she want to set, including amount of dowry that she wanted to get out of her future husband.These requirements are set in front of two witnesses in front of Qadi, who then puts them in the presence of the bridegroom to witness whether the man receives the requested requirements. ${ }^{54}$ According to the authors, the concept of women's rights protection before marriage begins from rights of the freedom of a woman to choose prospective husbands, the right to determine requirements of marriage mentioned before marriage held, the right to declare the agreement or do not agree to make a wedding by the guardian carried by Asghar is in accordance with the concept of the woman "s protection contained in the Act 303 Islamic

Family Law Federal Territory 1984 Malaysia.The regulations contained in section 15 of Act 303 Islamic Family Law Federal Territory about engagement meant to protect women's rights, this regulation give attention by prevent the occurrence of a violation of women ${ }^{\text {ee }}$ right in marriage life. In Islam the engagement occurred when the existence of an agreement of both man and woman to make a marriage at certain time. In this case it is clear that except from the man who proposes to reserve the girl he wanted, the women also have equal rights to accept or reject pinangan from man. About the rights to get goods that have been given at the time of the engagement in this case actually section 15 Islamic Family Law Federal Territory 1984 Malaysia not specifically follow one scholar but it is mix of opinions from four scholar (madzdhab) i.e Safiei Maliki, Hanafi and Hanbali. The parties cancels the engagement can be required to return all items that have been given at the time of engagement when one party feels damaged.In section 15 explains that not only obliged to return an item that has been given away, however, can be demanded in accordance with the amount of losses suffered by either party in

\footnotetext{
52 Ihromi, Irianto, and Luhulima, Penghapusan Diskriminasi Terhadap Wanita, 148.

${ }^{53}$ Engineer, Hak-Hak Perempuan Dalam Islam, 151.

${ }^{54}$ Engineer, Hak-Hak Perempuan Dalam Islam, 138.
}

Jurisdictie: Jurnal Hukum dan Syariah Vol. 6 No. 2 Desember 2015 
the event preparation of wedding where. In the case of engagement cancellation most aggrieved party is the party of women who are preparing a wedding. For Asghar, marriage is a mere contract that not only man has the authority but also woman has authority .In Asghar view, this article has applied his fundamental concept of marriage. In his view, marriage is merely contract between men and women.

Therefore, every action that related to the marriage must be discussed and based onthe agreement between husband and wife. Also in the term of engagement, according to Asghar view the step of engagement must contain of agreement to do marriage between a man and woman. This agreement will explain the intention of man and woman. The establishment of regulations regarding Islamic family law in the form of the legislation or Act actually has a specific purpose. The goal of the Islamic family law reforms in several countries including Indonesia are:to provide legal certainty for marital problems, because before any family legislation is only have the characteristic judge made law. to protect the women ${ }^{\text {ee }}$ right and at the same time meet the wishes and expectations of women. Family Law Act regulates and codified the obligations of husband as rights that must be obtained by the wife in the law regulation ${ }^{55}$ to creating laws that accordance with demands and the development of the times. In the contextualization of Islamic family law does not ignore the social, cultural and societal conditions factors. However, in terms the characteristic of family law Act both in terms of the principle, purpose and characteristics are raised the dignity and status of women (wives). If analyzed from section 15 Islamic Family Law Federal Territory 1984 Malaysia will be found an understanding that actually engagement is does not contains like marriage contract, does not contain a legal obligation and not also ensures the implementation of the marriage, but in terms of this section is binding on the parties to keep the commitment.

Then to create a situation where man and woman can keep this commitment, then this section gives the effect that the party in breach of responsibility to perform an engagement without any true reason must return the gift or the value of the gift received from the other party. In addition, he will also have to provide compensation for the preparation of engagement and wedding party.This section further pay attention to all possible violations of woman es rights before marriage held where the Islamic family laws of Indonesia has yet to pay attention of this. According to this article, the party canceled the engagement not only liable to bear the costs incurred in other parties, but also bear the costs of parents and family that has been used for preparation of engagement and wedding party. Riffat Hassan said that in this time we should develop what called by western as "teologi feminis" in Islamic context with the purpose to give freedom not only for muslim woman but also muslim man from structure of Law which is not equal. This structure and Law lead to the impossibility of life relation between man and woman. ${ }^{56}$ Man and woman are equal, although there are biological differences and other differences. According to the Holy Qurean, Allah create man and woman are equal. They created together and have the same substantion, and also have the same ways of creation. ${ }^{57}$

Based on the view of Riffat Hassan and Fatima Mernissi the position of man and woman are equal. This condition can create by the regulation that responsive to gender issues. The regulation in the forrm of Law or Act cen support the equality between man and woman and

\footnotetext{
${ }^{55}$ Mufidah Ch, Isu-Isu Gender Kontemporer Dalam Hukum Keluarga (Malang: UIN-Maliki Press, 2010 ), 64.

${ }^{56}$ Fatima Memissi and Riffat Hassan, Setara Di Hadapan Allah, Relasi Perempuan Dan Laki-Laki Dalam

Tradisi Pasca Patriarkhi (Yogyakarta: Yayasan Prakarsa, 1995), 40.

${ }^{57}$ Memissi and Hassan, Setara Di Hadapan Allah, Relasi Perempuan Dan Laki-Laki Dalam Tradisi Pasca Patriarkhi, 61.
}

Jurisdictie: Jurnal Hukum dan Syariah Vol. 6 No. 2 Desember 2015 
also support to protect to woman "es right if it arranged based on equality between man and woman because basiacally man and woman are equal in the right and obligation. The opinion of Asgar is following the view of Qasim Amin. He argues that women must be accepted as equal with absolute freedom as retrieved by a man there is no difference in the absolute both in absorbs knowledge. So they must be given the same rights in all life aspect. He said that leading scientists and scholars said that woman have the same intellect with man. ${ }^{58}$ Qasim Amin explain that woman is person like a man, there is no difference if seen from the body, assignment, feeling, thinking and all aspect that related to human essence. If there is differences between both, it is merely influence of different types. ${ }^{59}$

In marriage, Qasim Amin feels need to review the issue marriage in order to improve the structure of the family, because the family still related to customs law and Shari'ah law. ${ }^{60}$ See the thats opinion the establishment regulation of Family Law in Malaysia throught Act 303 Islamic Family Law Federal Territory has the purpose to regulate the using of custom law related to Marriage and Family law to be accordance and responsive to gender isues. This done because some of custom related to marriage damage woman's rights like engagement. According to his observations, there are views in the community that humiliate women's position in marriage. Women only as objects of marriage. These negative views are not only among the laities but also among fuqha. Qasim Amin wanted to raise the degree of women from object to the same level with man. Woman become the subject of marriage. Therefore he opposed the unilateral option, i.e. from the man only who can determines the choice in marriage. He said women should be given the opportunity to choose her soul mate and she got divorced right.134 Qasim Amin thought is an attempt to raise back the dignity (marwah) of women, in accordance with the teachings of islam, so that women are able to carry out her duties as a wife, as the first and foremost educators of children, as well as members of good community. This view is accordance with the purpose of Islamic family law reform in Malaysia trough Act 303 Islamic Federal Territory 1984.

\section{Conclusion}

Engagement cancellation in Malaysia has the legal implication. Based on Family Law Legislation in Malaysia. Engagement is considered as a contract that bond man and woman. Engagement cancellation in Malaysia is not only set in Act 303 Islamic Family Law Federal Territory, but also set in enactment from all states in Malaysia that has the same arrangement. According to the previous section, it can be seen that an engagement is a kind of thing which has an implication, it is about law that is able to bond both two parties until it has the same meaning with a contract. The implication of engagement itself could open the opportunities to both of bride and groom to understand and know each other. The implications of engagement cancellation that can be taken from section 15 Act 303 Islamic Family Law Federal Territory that are: The only one side who cancel the engagement have to return all the gift and give the requisites replacement change, For the one who has the unwilling engagement without any reasonable reason will be punished to replace all the gifts, and The one side who cancel the engagement should pay the things that has already spent to prepare the engagement and wedding party. It has explained clearly that an engagement is protected by the law Act. The

\footnotetext{
${ }^{58}$ Qasim Amin, Sejarah Penindasan Perempuan: Menggugat "Islam Laki-Laki”, Menggugat "Perempuan Baru” (Yogyakarta: IRCiSoD, 2003), 60.

${ }^{59}$ Qasim Amin, Tahrir Al-Mar'ah (Kairo: Dar al-Ma'arif, 1993), 41.

${ }^{60}$ Amin, Tahrir Al-Mar'ah, 84.
}

Jurisdictie: Jurnal Hukum dan Syariah Vol. 6 No. 2 Desember 2015 
parties who feel detrimented because of engagement cancellation can make prosecution in Syariah Court.

Regulation of Islamic Family Law in Malaysia especially Act 303 Islamic Family Law federal Territory contains of woman's rights protection. It has a sense protection towards women's rights and meet practical gender needs. In Islamic family law in Malaysia especially Act 303 Federal Territory Islamic Family Law 1984 women have rights in accordance with their position, namely in the form of rights before marriage, the rights within marriage and the last is the rights after divorce. Women's rights protection aspects contained in the Act 303 Islamic Family Law Federal Territory generally not only in case of engagement cancellation or breach of promise of marriage (bethrothal) but in all the rights of women in marriage. It has the purpose to protect women's rights. This regulation give attention by prevent the occurrence of a violation of women's right in marriage life. The woman's protection Aspect contained in Act 303 Islamic Family Law Federal Territory 1984 Malaysia is accordance with the some views of gender figure such as Asghar Ali Engineer, Qasim Amin, and other views of woman's rights. They support the protection of woman's right in family law and consider man and woman are equal in their position in family.

\section{Bibilography}

Amin, Qasim. Sejarah Penindasan Perempuan: Menggugat "Islam Laki-Laki", Menggugat "Perempuan Baru." Yogyakarta: IRCiSoD, 2003. Tahrir Al-Mar'ah. Kairo: Dar al-Ma'arif, 1993.

Azmi, Tun Zaki bin Tun Mohamed. "Singapore Academy of Law Annual Lecture 2011-The Common Law of Malaysian in the 21st Century." Singapore Academy of Law Journal 24, no. 1 (March 2012).

Engineer, Asghar Ali. Hak-Hak Perempuan Dalam Islam. Translated by Farid Wajidi and Cici Farkha Assegaf. Yogyakarta: Lembaga Studi dan Pengembangan Perempuan dan Anak, 2000. . "Islam, Women, and Gender Justice." In What Men Owe to Women: Men's Voices from World Religions, edited by John C Raines and Daniel C Maguire. New York: State University of New York Press, 2001.

Fuadi, M. Samir. "Peran Urf Dalam Formalisasi Hukum Peminangan Di Malaysia Dan Pakistan Menurut Tinjauan Dalil Al-Qur'an Dan Sunnah.” Al-Mu 'ashirah 10, no. 1 (January 2013).

“Hak-Hak Di Dalam Undang-Undang Keluarga Islam.” Accessed January 29, 2015. http://senadakpwkm.wordpress.com/2011/02/14/hak-hak-di-dalam-undang-undangkeluargaislam/.

Hasan, Zulkifli. "Hak-Hak Wanita Islam Dalam Kes Mungkir Janji Untuk Berkahwin Di Malaysia : Kajian Perbandingan Antara Undang-Undang Sivil Dan Syariah.” Jurnal Hukum 20, no. 1 (2005).

Hasyim, Noraini Binti Md. "Right of Muslim Women before and during Marriage, and Upon Divorce as Conferred by The Islamic Family Law (Federal Territories Act) 1984, Malaysia." Faculty of Liberal Art Prince Sonkla University, 2015.

Ibrahim, Ahmad. Undang-Undang Keluarga Islam Di Malaysia. Kuala Lumpur: Malaysian law Journal, 2000.

Idris, Noriah. "Dilema Putus Tunang." Accessed February 6, 2015. http://musaawang.blogspot.co.id/2011/11/dilema-putus-tunang.html.

Ihromi, T. O., Sulistyowati Irianto, and Achie S. Luhulima. Penghapusan Diskriminasi Terhadap Wanita. Bandung: Alumni, 2000.

Jurisdictie: Jurnal Hukum dan Syariah Vol. 6 No. 2 Desember 2015 
Legal Research Board. Islamic Family Law (Federal Territories) Act 1984 (Act 303). Malaysia: International Law Book Service, 2012.

Majid, Mimi Kamariah. Undang-Undang Keluarga Di Malaysia. Kuala Lumpur: Butterworths Asia, 1992.

Marzuki, Peter Mahmud. Penelitian Hukum. Jakarta: Kencana, 2010.

Memissi, Fatima, and Riffat Hassan. Setara Di Hadapan Allah, Relasi Perempuan Dan LakiLaki Dalam Tradisi Pasca Patriarkhi. Yogyakarta: Yayasan Prakarsa, 1995.

Mohamad, Abdul Hamid. "Harmonisation of Common Law and Shari'ah in Malaysia: A Practical Approach." Accessed October 4, 2015. http://www.malaysianbar.org.my/speeches/harmonisation_of_common_law_and_shari ah_in_malaysia_a_practical_approach.html.

Mufidah Ch. Isu-Isu Gender Kontemporer Dalam Hukum Keluarga. Malang: UIN-Maliki Press, 2010.

Naily, Nabiela, and Kemal Riza. "Hukum Keluarga Islam Asia Tenggara Kontemporer: Sejarah, Pembentukan, Dan Dinamikanya Di Malaysia.” Executive Summary. Surabaya: LP2M IAIN Sunan Ampel, 2013.

Nuraisyah Chua Abdullah. Family Law for Non-Muslims in Malaysia. Selangor: International Law Book Services, 2006.

Nuruddin, Amiur, and Azhari Akmal Tarigan. Hukum Perdata Islam di Indonesia: Studi Kritis Perkembangan Hukum Islam dari Fikih, UU No. 1/1974, Sampai KHI. Jakarta: Kencana, 2004.

"Pemungkiran Pertunangan.” Accessed March 4, 2017. https://senadakpwkm.wordpress.com/2011/02/16/pemungkiran-pertunangan/.

Qardhawi, Yusul al-. Al-Ijtihad Al-Mu'asir Bain Al-Indibat Wa Al-Infirat. Kairo: Dar alTauzi, 1992.

Qureshi, Mohammed Ahmad. Muslim Law of Marriage, Divorce and Maintenance. New Delhi: Deep \& Deep Publications, 1995.

"Salbiah Othman Lwn Hj. Ahmad Abdul Ghani." Accessed March 4, 2015. http://www.esyariah.gov.my/JurnalHukumSearch/htdocs/jurnalhukumsearch/JurnalHu kumSearchDetailsPageBM.jsp.

Salleh, Anis Shuhaiza Bt Md, and Noor 'Aza Bt Ahmad. "Cross Boundary Marriage Under Malaysian Family Law: Between a Dream of Life and Reality of Legal Requirements." Journal of Politics and Law 3, no. 2 (September 2010): 148. doi:10.5539/jpl.v3n2p148.

Shuaib, Farid S. "The Islamic Legal System in Malaysia." Pacific Rim Law \& Policy Journal 21, no. 1 (January 2012).

Tim Penyusun. Pedoman Penulisan Karya Ilmiah Fakultas Syariah. Malang: Fakultas Syariah UIN Maulana Malik Ibrahim Malang, 2012.

Zin, Najibah M. "The Training, Appointment, and Supervision of Islamic Judges in Malaysia.” Pacific Rim Law \& Policy Journal 21, no. 1 (January 2012). 